\title{
Trends in aquatic ecology research associated with urbanization evolution during three decades in Santa Catarina Island/SC
}

Tendências em pesquisas de ecologia aquática associadas com a evolução da urbanização durante três décadas na Ilha de Santa Catarina/SC

\section{Michelle das Neves Lopes ${ }^{1 *}$ (D), Felippe Luiz Dalpiaz ${ }^{1}$ (D), Bruno Rech² (D), \\ Julia Daniel Teixeira $^{1}$ (D), Isabella Seelig Soares Ribeiro ${ }^{1}$ (D), Danton Magri ${ }^{1}$ (D), \\ Daniela Grijó de Castro $^{3}$ (D), Maurício Mello Petrucio $^{1}$ (D) and Nei Kavaguichi Leite ${ }^{1}$}

${ }^{1}$ Departamento de Ecologia e Zoologia, Universidade Federal de Santa Catarina, Campus Universitário, s/n, Sala 007, Bloco B, térreo - Córrego Grande- CEP: 88.040-900, Florianópolis, SC, Brasil

${ }^{2}$ Curso de Engenharia Sanitária e Ambiental, Universidade Federal de Santa Catarina - UFSC, Campus Universitário - Trindade, Caixa Postal: 476 - CEP: 88.040-970, Florianópolis, SC, Brasil

${ }^{3}$ Universidade Federal de Viçosa - UFV, Av. Peter Henry Rolfs, s/n - Campus Universitário, CEP: 36570-900, Viçosa, MG, Brasil

*e-mail: michellenlopes@gmail.com

Cite as: Lopes, M.N. et al. Trends in aquatic ecology research associated with urbanization evolution during three decades in Santa Catarina Island/SC. Acta Limnologica Brasiliensia, 2020, vol. 32, e205.

Abstract: This paper systematically assessed trends of aquatic ecology publications related to the urbanization growth during three decades (1990-2010) in Santa Catarina Island. The study was carried out in fifteen watersheds of Santa Catarina Island, located in Florianópolis city, Southern Brazil. Geoprocessing and scientometry tools were used to analyze the evolution of urban areas and publications, respectively, related to these watersheds during three decades. The QGIS software was used to delimitate the catchment area of each watershed and contrast those areas with the built-up area for each decade, therefore obtaining the percentage of area covered with buildings and impervious surfaces. A gradient was created allowing the classification of the watersheds related to the urbanized area percentage, resulting in 5 groups of urbanization $(0-5 \% ; 5-10 \% ; 10-20 \% ; 20-30 \% ;>30 \%$ of urbanization). Aquatic ecology publications were obtained from several scientific and academic databases and used in the scientometric analysis. The number of publications by decade, document type, knowledge area and watershed of study were recorded. Growth of urbanized areas was mainly evidenced since the 2000s and showed a moderate positive relationship with the number of publications in ecology of aquatic systems in the Santa Catarina Island during the same period. However, differences between watersheds were observed, since the most urbanized watersheds were not necessarily the ones with the largest number of publications. Urban gradient evidenced in Santa Catarina Island offers an opportunity to investigate the impacts of human disturbance on aquatic ecology, water quality and stream communities. Furthermore, the low number of research projects might be contributing to the decline in biological integrity due to the lack of knowledge for evaluation and management in these environments.

Keywords: watersheds; freshwater; geoprocessing; scientometry; land use.

Resumo: Este artigo avaliou sistematicamente as tendências das publicaçôes de ecologia aquática relacionadas ao crescimento da urbanização durante três décadas (1990-2010) na Ilha de Santa Catarina. O estudo foi realizado em quinze bacias hidrográficas da Ilha de Santa Catarina, localizadas na cidade 
de Florianópolis, Sul do Brasil. Ferramentas de geoprocessamento e cienciometria foram utilizadas para analisar a evolução das áreas urbanas e publicações, respectivamente, relacionadas a essas bacias hidrográficas durante três décadas. O software QGIS foi utilizado para delimitar a área de captaçáo de cada bacia hidrográfica e contrastar essas áreas com a área construída para cada década, obtendo a porcentagem de área coberta por construçóes e áreas impermeabilizadas. Foi criado um gradiente que permite classificar as bacias hidrográficas em relação à porcentagem da área urbanizada, resultando em 5 grupos de urbanização $(0-5 \% ; 5-10 \% ; 10-20 \% ; 20-30 \% ;>30 \%$ da urbanização). As publicaçóes sobre ecologia aquática foram obtidas de diversas bases de dados científicas e acadêmicas e foram utilizadas na análise da cienciometria. Foram registrados o número de publicaçóes por década, tipo de documento, área de conhecimento e bacia hidrográfica do estudo. O crescimento das áreas urbanizadas foi evidenciado principalmente a partir da década de 2000 e mostrou uma relaçáo moderada positiva com número de publicaçóes em ecologia de sistemas aquáticos na Ilha de Santa Catarina durante o mesmo período. No entanto, foram observadas diferenças entre as bacias hidrográficas, onde as bacias mais urbanizadas náo foram necessariamente aquelas com maior número de publicaçóes. O gradiente urbano evidenciado na ilha de Santa Catarina oferece uma oportunidade para investigar os impactos da perturbação humana na ecologia aquática, qualidade da água e comunidades de riachos. Além disso, o baixo número de pesquisas pode estar contribuindo para o declínio da integridade biológica devido à falta de conhecimento para avaliação e gerenciamento nesses ambientes.

Palavras-chave: bacias hidrográficas; água doce; geoprocessamento; cienciometria; uso do solo.

\section{Introduction}

Freshwater systems on subtropical islands are undergoing substantial alteration as urbanization increases, and these watersheds become different from native stream communities (Brasher, 2003). Human population continues to move to cities and managing water quality and sanitation is probably the biggest challenge of this century (Kaushal et al., 2010).

Changes in populations and associated socioeconomic factors drive the intensity, extent, and stage of urban development, and may affect freshwater ecosystems on a temporal-spatial scale (Parr et al., 2016). Uncontrolled urbanization has the potential to affect ecosystem functions of aquatic ecosystems by altering the hydrologic regime (runoff), habitat loss (riparian cover removal), and physicochemical characteristics (inputs of nutrients and pollutants) (Walsh et al., 2005; Parr et al., 2016), threatening the environmental health (Cooper et al., 2013; Liao \& Huang, 2013)

Effective water quality management of streams in urbanized watersheds requires the identification of the most important contributors to changes in the environment, such as sources of pollutants (Hatt et al., 2004). Thereby, urbanization has led to increased research on ecology in urban ecology in the last decades worldwide (Smucker \& Detenbeck, 2014; Walsh et al., 2005).

Recently, an increasing number of ecologists have collaborated with other scientists, planners, and engineers to understand and even shape these ascendant ecosystems (Grimm et al., 2008). Urban ecological studies have investigated both impacts of urban development on native ecosystems and the dynamics of urban environments themselves as ecosystems (Grimm et al., 2000).

Santa Catarina Island is localized in a subtropical climate area and has been a key touristic destination in Brazil (Wemple et al., 2017). Consequently, there has been observed an increased urbanization and population growth in the last decade (Guerra et al., 2016). On the island, the aquatic ecosystems are mainly formed by lagoons, rivers and streams usually of short extension (Pêgas Filho \& Tirloni, 2009). The continued development of urban ecosystems on the island has the potential to change the integrity of the aquatic ecosystem, where the understanding of the integrative context will be important for water resources management.

Scientometric tools have been used to measure scientific progress, and are a common research instrument for systematic analysis (Van Raan, 2005). The results could provide a better understanding of the local trend in aquatic ecosystem research and, potentially, give some guidance for future studies and assist policy-makers for water management.

Hence, this paper aims to assess, systematically, the trends of aquatic ecology publications associated with the urbanization evolution during three decades (1990, 2000 and 2010) in Santa Catarina Island, using geoprocessing and scientometry tools.

\section{Methods}

\subsection{Study area}

The study was carried out in Santa Catarina Island $\left(27^{\circ} 34^{\prime} \mathrm{S} 48^{\circ} 27^{\prime} \mathrm{O}\right)$, located in Florianópolis city, Southern Brazil (Nascimento, 2002). The insular area is about $423 \mathrm{~km}^{2}$, with $42 \%$ of 
the area established as permanent preservation areas (IPUF, 2004). However, since the 20th century, urbanization contributed to the development of the city, and it has attracted tourists, resulting in even more growth (Wemple et al., 2017). In 2010s, almost $100 \%$ of the urbanizable areas of Santa Catarina Island - in other words, areas with no physical limitations (mainly mountain chains) were occupied (IBAM, 2015; Santiago et al., 2014). Here we studied the fifteen major watersheds of Santa Catarina Island (Figure 1).

\subsection{Geoprocessing}

An urbanization gradient was used, which enabled the investigation of urbanization evolution over three decades (1990-2010). Firstly, a Digital Elevation Model (DEM) with $30 \mathrm{~m}$ of spatial resolution from the Santa Catarina State data repository (SIGSC, 2017) was accessed. To delimitate the drainage area of each watershed, the algorithm r.watershed (GRASS GIS 7), was implemented in the QGIS software (QGIS, 2019). Afterwards, the watershed perimeter with the built-up areas for each decade (1993, 2003 and 2013) was clipped to obtain the percentage of area covered by buildings. The present built-up areas (scale: 1:50.000) were provided by the Institute of Urban Planning of Florianópolis - IPUF. Thus, a gradient was created to classify the watersheds according to urbanized area percentage: beige ( $0-5 \%$ of urbanization), yellow $(5-10 \%)$, orange $(10-20 \%)$, red $(20-30 \%)$ and dark red (>30\%) (Figure 1).

\subsection{Scientometrics}

To evaluate the publications on aquatic systems in Santa Catarina Island, we have applied a workflow, as suggested by PRISMA (2020) (Figure 2). The used databases were obtained from the Institute for Scientific Information (ISI), the Web of Science database, the Science Citation Index (SCI), the Google Scholar and the Institutional Repository of Federal University of Santa Catarina (DSpace). The keywords used for retrieving data were "aquatic ecosystem" or "water ecosystem" or "hydrology", or "ecology", or "limnology" and the watershed's name. These terms yielded many non-

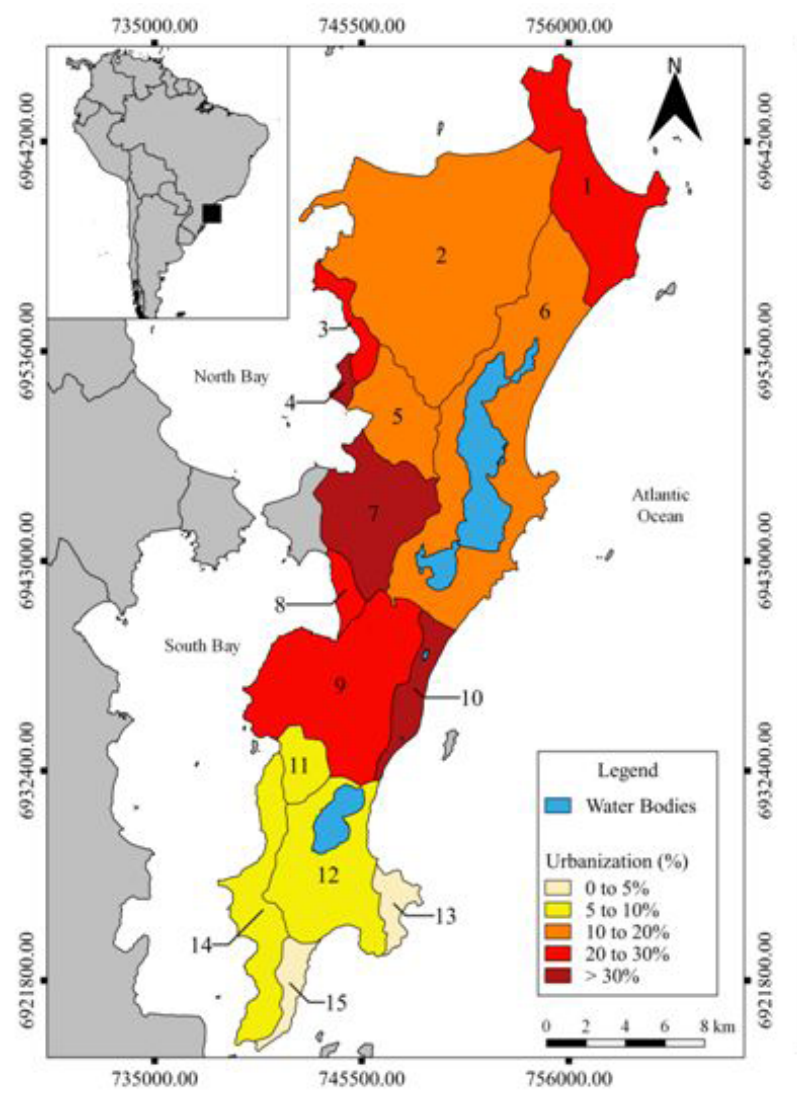

\begin{tabular}{|c|c|}
\hline $\begin{array}{l}\text { 1-Ingleses } \\
\text { Drain. area: } 33.09 \mathrm{Km}^{2} \\
\text { Urb.: } 29.25 \% \quad \text { Pub: } 07\end{array}$ & $\begin{array}{l}\text { 9- Rio Tavares } \\
\text { Drain. area: } 50.31 \mathrm{Km}^{2} \\
\text { Urb.:22.58\% Pub : } 31\end{array}$ \\
\hline $\begin{array}{l}\text { 2-Ratones } \\
\text { Drain. area: } 98.42 \mathrm{Km}^{2} \\
\text { Urb.: } 12.25 \% \text { Pub : } 36\end{array}$ & $\begin{array}{l}\text { 10- Morro das Pedras } \\
\text { Drain. area: } 9.30 \mathrm{Km}^{2} \\
\text { Urb.: } 41.80 \% \text { Pub : } 10\end{array}$ \\
\hline $\begin{array}{l}\text { 3-Sto. Antorio Lisboa } \\
\text { Drain. area: } 5.28 \mathrm{Km}^{2} \\
\text { Urb.: } 23.26 \% \text { Pub : } 05\end{array}$ & $\begin{array}{l}\text { 11- Tapera } \\
\text { Drain. area: } 7.36 \mathrm{Km}^{2} \\
\text { Urb.:9.82\% Pub : } 11\end{array}$ \\
\hline $\begin{array}{l}\text { 4-Cacupé } \\
\text { Drain. area: } 1.90 \mathrm{Km}^{2} \\
\text { Urb.: } 35.7 \% \text { Pub : } 07\end{array}$ & $\begin{array}{l}\text { 12-Lagoa do Peri } \\
\text { Drain. area: } 36.29 \mathrm{Km}^{2} \\
\text { Urb.: } 5.32 \% \text { Pub : } 66\end{array}$ \\
\hline $\begin{array}{l}\text { 5-Saco Grande } \\
\text { Drain. area: } 16.85 \mathrm{Km}^{2} \\
\text { Urb.: } 15.96 \% \text { Pub : } 15\end{array}$ & $\begin{array}{l}\text { 13- Lagoinha do |Leste } \\
\text { Drain. area: } 6.22 \mathrm{Km}^{2} \\
\text { Urb.:0\% Pub : } 08\end{array}$ \\
\hline $\begin{array}{l}\text { 6- Lagoa da Conceição } \\
\text { Drain. area: } 86.02 \mathrm{Km}^{2} \\
\text { Urb.: } 10.55 \% \text { Pub : } 46\end{array}$ & $\begin{array}{l}\text { 14-Ribeirão da Ilha } \\
\text { Drain. area: } 20.95 \mathrm{Km}^{2} \\
\text { Urb.:6.11\% Pub : } 10\end{array}$ \\
\hline $\begin{array}{l}\text { 7-Itaconubi } \\
\text { Drain. area: } 29.05 \mathrm{Km}^{2} \\
\text { Urb:: } 40.68 \% \text { Pub : } 53\end{array}$ & $\begin{array}{l}\text { 15-Saquinho } \\
\text { Drain. area: } 6.17 \mathrm{Km}^{2} \\
\text { Urb::0.06\% Pub : } 03\end{array}$ \\
\hline $\begin{array}{l}\text { 8-Costeira } \\
\text { Drain. area: } 5.25 \mathrm{Km}^{2} \\
\text { Urb.: } 22.33 \% \text { Pub : } 08\end{array}$ & \\
\hline
\end{tabular}

Figure 1. Study area map of the Santa Catarina Island - SC, Brazil. The watersheds are aggregated by urbanization gradient (beige: $0-5 \%$; yellow: $5-10 \%$; orange: $10-20 \%$; red: $20-30 \%$; dark-red: $>30 \%$ of urbanization), drainage area and publications number. 


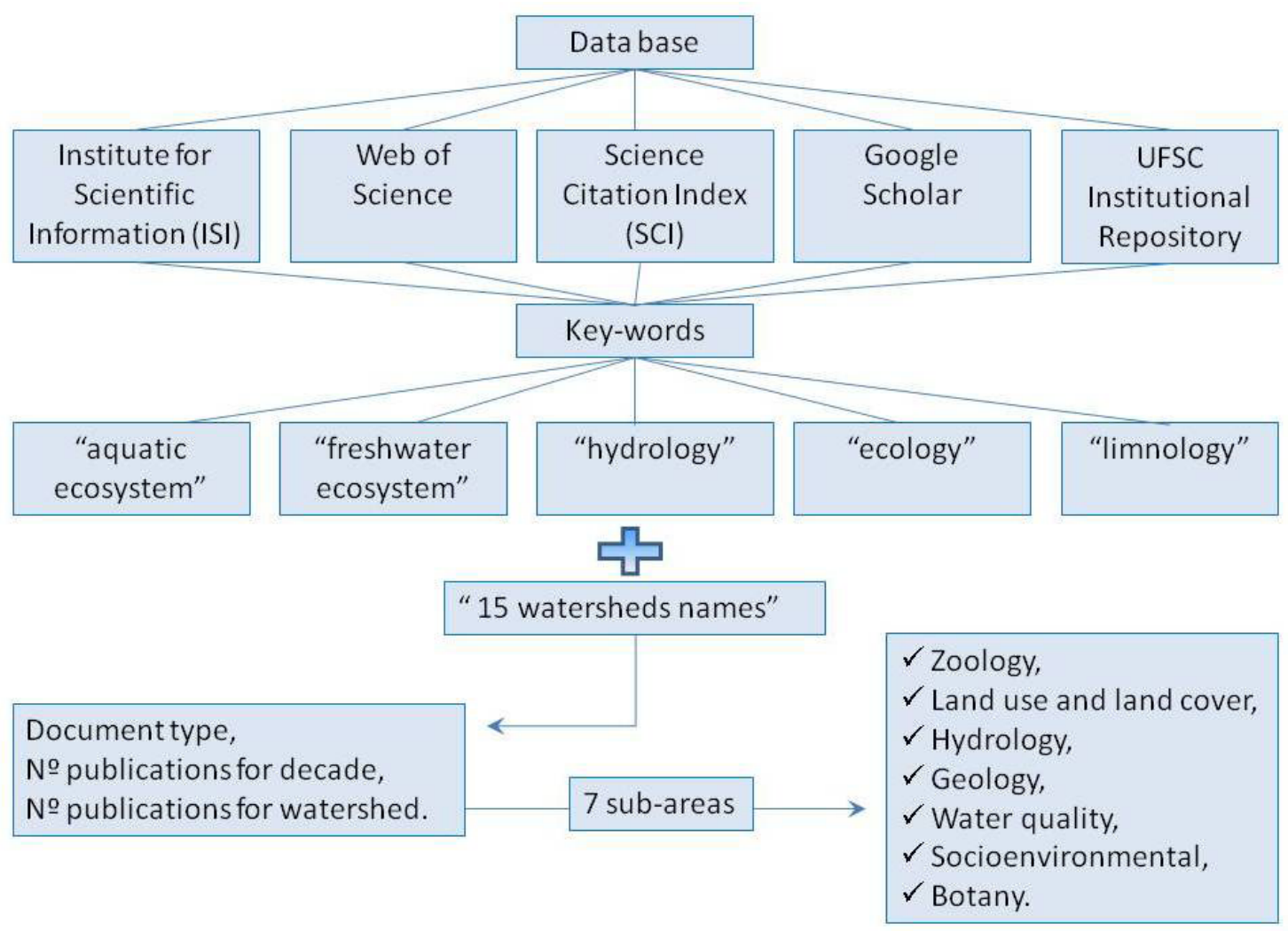

Figure 2. Workflow with filters used to evaluate the publications on aquatic systems in Santa Catarina Island (as suggested by PRISMA).

relevant studies, being necessary an inspection to verify whether they really addressed aspects related to aquatic ecology. Searches were restricted to the period from 1979 to 2018, and were finalized in May 2019.

Afterwards, the publication outputs, document type, number of publications by decade, and studied watershed information were noted from the selected studies. The information was then grouped by knowledge areas and stored in a database of technical (congress abstracts and technical reports) and scientific (articles, doctoral thesis and master's dissertations, completion of course works) documents related to Florianópolis watersheds. From the 212 publications registered, 181 were carried out for a single watershed, while the others addressed two or more watersheds. The studies investigating more than one watershed were computed with repetition to identify the exact number of researches for each watershed individually.

We defined seven knowledge areas within aquatic ecology publications as follows: zoology, land use and land cover, hydrology, geology, water quality, socio-environmental and botany.

\subsection{Statistical analyses}

To analyze the results, both urbanization area and outputs were classified in three decades, with the first decade (Dec1) comprising the period until 1999 (1979-1999), the second decade (Dec2) until 2009 (2000-2009) and the third decade (Dec3) until 2019 (2010-2019).

We used a non-parametric Kruskal-Wallis H test to compare variations of the urbanization percent and numbers of aquatic ecology studies among the three decades previously described. Statistical significance was calculated using Chi-square test $\left(\chi^{2}\right)$ and set $p$-value $<0.05$. When a significant difference was detected, a pairwise test for multiple comparisons of ranked data (Conover's post-hoc test) with a Bonferroni correction was performed in order to explore these differences between decades using the PMCMRplus package (Dinno, 2017).

Spearman's Correlation Analysis was performed using all studied watersheds, in order to evaluate the correlation of total urbanization increase with aquatic ecology studies. Besides, we analyzed the correlation between the urbanized areas of each watershed and the number of publications 
and watershed drainage area and the number of publications. Statistical significance was calculated using the Chi-square test $\left(\mathbf{X}^{2}\right)$ and set $\mathrm{p}$-value $<0.05$. For this analysis, we used the package 'pspearman' (Savicky, 2015). We used nonparametric statistics after no normal distribution was found ( $p$-value $>0.05$; Shapiro Test). All statistical analyses were performed using the software R Studio version 1.1.383 (R Development Core Team, 2015).

\section{Results}

\subsection{Gradient of urbanization}

The greatest urbanization boom occurred between the 1990s and the 2000s. The Santa Catarina Island showed a total urban area of $8 \%$ in 1993 , increasing to $14 \%$ in 2003 and reaching 16\% in 2013 (Figure 3).

Although total urbanization has increased two-fold in three decades, the watersheds showed a different urban growth. However, there were no significant differences in urbanization increase of the watersheds between the three decades $(\mathrm{X} 2(\mathrm{df}=2 \mathrm{~N}=45)=5.11, \mathrm{p}$-value $=0.07)$. Over the three decades, the watersheds that showed the greatest growth in urbanized areas were Saco Grande, Rio Tavares, Morro das Pedras, Santo Antônio de Lisboa, Ingleses, Costeira, Cacupé, and Itacorubi (Table 1).

Watersheds that showed in the 90s about 6 and $10 \%$ of urbanized area, such as Saco Grande, Rio Tavares, and Morro das Pedras, revealed a strong increase in the following decades. Morro das Pedras watershed showed the highest degree of urbanization in Santa Catarina Island in the 2010s, exceeding $41 \%$ of the total area (Figure 1 ). Although it is the smallest watershed on the Island, almost $50 \%$ of the total area is urbanized.

In the 1990s, Santo Antônio de Lisboa, Ingleses, Costeira and Cacupé already had considerable urban areas between 11 and $20 \%$ of the total area, which increased in the subsequent decades. Cacupé showed the most expressive growth, reaching 35\% of urbanized area in the 2010s. Itacorubi was the most urbanized watershed during the 1990s, and in the following decades, it was considered the second most urbanized watershed of Santa Catarina Island (Figure 1).

Spearman's correlation showed not significant association between urbanization and watershed area $\left(r_{s}(13)=-0.14\right.$, p-value $\left.=0.06\right)$.
A

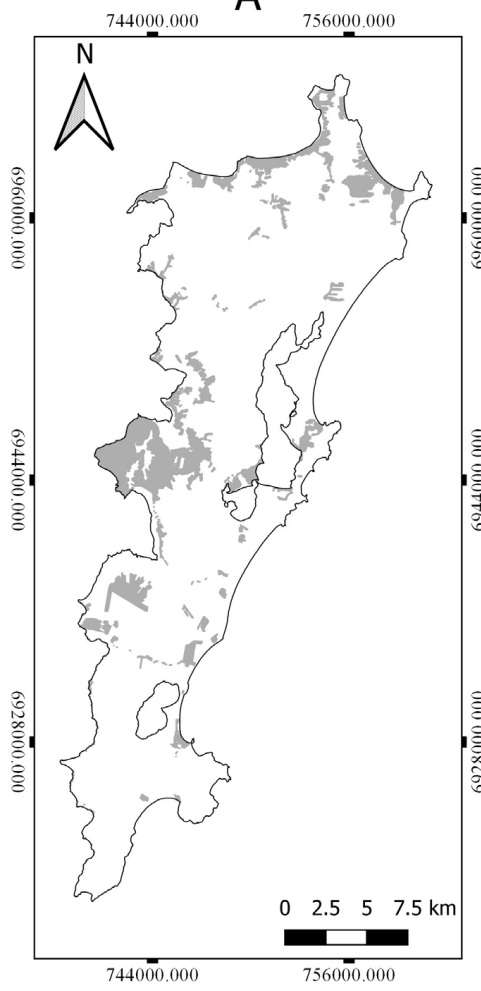

B

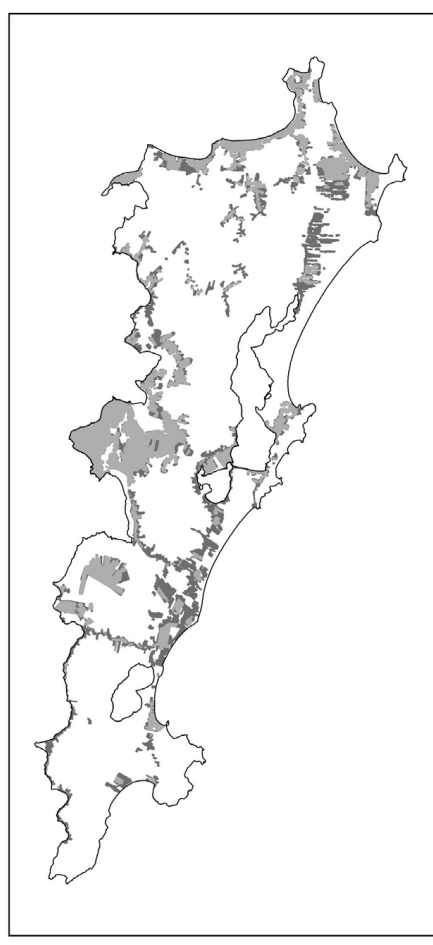

C

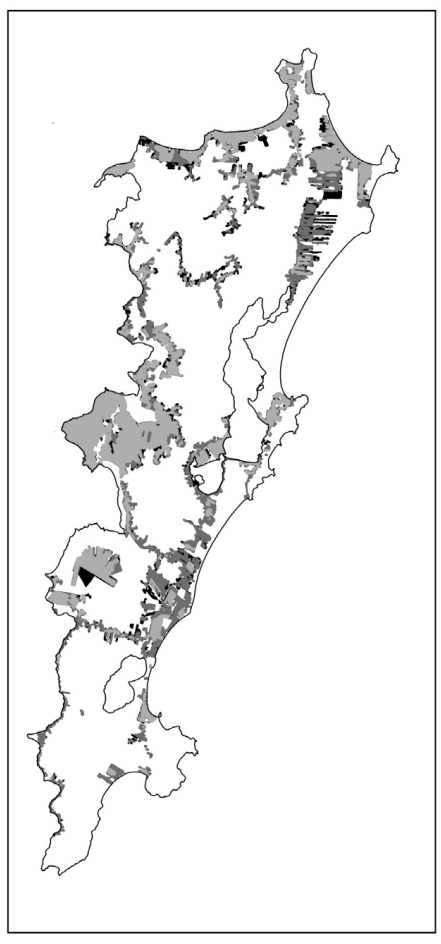

Figure 3. Urban evolution maps of Santa Catarina Island. The maps show the urbanized area of $8 \%$ in (A) 1993 (light grey); (B) urbanized area of 14\% in 2003 (medium grey); and (C) urbanized area of 16\% in 2013 (dark grey). 
Table 1. Watersheds studied in Santa Catarina Island, drainage areas, number of studies, and urbanization percentage of the last three decades.

\begin{tabular}{|c|c|c|c|c|c|c|c|}
\hline \multirow[b]{2}{*}{ Watersheds } & \multirow[b]{2}{*}{ Area $\mathrm{Km}^{2}$} & \multicolumn{3}{|c|}{ Publications ( $\mathrm{N}^{\circ}$ ) } & \multicolumn{3}{|c|}{ Urbanization (\%) } \\
\hline & & $\begin{array}{c}\text { Dec.1 } \\
1979-90\end{array}$ & $\begin{array}{c}\text { Dec. } 2 \\
2000\end{array}$ & $\begin{array}{l}\text { Dec. } 3 \\
2010\end{array}$ & $\begin{array}{c}\text { Dec.1 } \\
1993\end{array}$ & $\begin{array}{l}\text { Dec.2 } \\
2003\end{array}$ & $\begin{array}{c}\text { Dec. } 3 \\
2013\end{array}$ \\
\hline Saquinho & 6.17 & 0 & 2 & 1 & 0.0 & 0.06 & 0.06 \\
\hline Sto Antônio de Lisboa & 5.28 & 1 & 2 & 2 & 12.1 & 23.3 & 23.3 \\
\hline Cacupé & 1.90 & 2 & 4 & 1 & 11.3 & 29.9 & 35.7 \\
\hline Ingleses & 33.09 & 3 & 2 & 2 & 17.1 & 23.9 & 29.2 \\
\hline Costeira & 5.25 & 2 & 3 & 3 & 11.3 & 20.9 & 22.3 \\
\hline Lagoinha do Leste & 6.22 & 1 & 2 & 5 & 0.0 & 0.0 & 0.0 \\
\hline Morro das Pedras & 9.30 & 1 & 5 & 4 & 6.0 & 36.4 & 41.8 \\
\hline Riberão da llha & 20.95 & 1 & 4 & 5 & 0.6 & 5.7 & 6.1 \\
\hline Tapera & 7.36 & 2 & 4 & 5 & 2.1 & 8.1 & 9.8 \\
\hline Saco grande & 16.85 & 0 & 8 & 7 & 9.4 & 16 & 16 \\
\hline Rio Tavares & 50.31 & 7 & 13 & 11 & 9.9 & 19.5 & 22.6 \\
\hline Ratones & 98.42 & 3 & 17 & 16 & 5.6 & 9.9 & 12.2 \\
\hline Lagoa da Conceição & 86.02 & 10 & 20 & 16 & 3.5 & 8.6 & 10.5 \\
\hline Itacorubi & 29.05 & 8 & 23 & 22 & 31.9 & 38.5 & 40.7 \\
\hline Lagoa do Peri & 36.29 & 2 & 15 & 49 & 1.9 & 5.3 & 5.3 \\
\hline
\end{tabular}

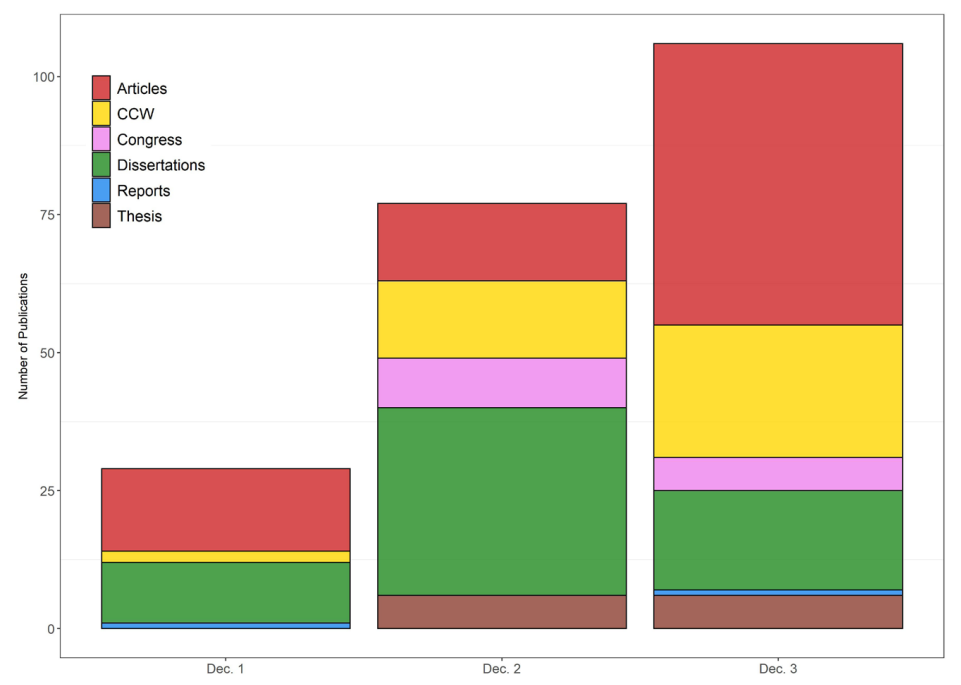

Figure 4. Number $(\mathrm{N})$ of publications in watersheds in Santa Catarina Island separated by document types in the last three decades $($ Red $=$ articles; Brown $=$ doctoral thesis; Green $=$ master's dissertation; Yellow $=$ completion of course works; Pink = congress abstracts; and Blue = technical reports).

\subsection{Scientometrics}

Researches on aquatic ecology in Santa Catarina Island watersheds began in 1979, with a technical report about floristics in nine watersheds. Our results showed 212 publications, demonstrating an increasing rate in the last three decades (Figure 4).

During the period from 1979 to 1999 , 29 publications were found. The fast-growing period started in the second decade (2000s), when the number of publications increased more than two-fold, reaching 77 publications. The same pattern was observed in the third decade analyzed, with 106 publications. The growth in the number of publications showed significant differences between the three decades evaluated $\left(\mathrm{X}^{2}(\mathrm{df}=2, \mathrm{~N}=45)=9.21\right.$, $\mathrm{p}$-value $=0.009)$. Where the first decade differs from the two subsequent decades ( $\mathrm{p}$-value $=0.015$ and $\mathrm{p}$-value $=0.022$, respectively).

Despite the number of publications having increased in the second decade, the number of articles was similar $(\operatorname{Dec} 1=15$, Dec2 $=14)$. In the same period, there was a substantial increase in academic research, such as dissertations, CCW, congress abstracts and thesis (Figure 4). On the other hand, the publication of articles increased in the third decade, reaching up to three times more than the previous decades $(\operatorname{Dec} 3=51)$. 
Five watersheds have shown the largest number of publications: Lagoa do Peri $(\mathrm{n}=66)$, Itacorubi $(\mathrm{n}=53)$, Lagoa da Conceição $(\mathrm{n}=46)$, Ratones $(\mathrm{n}=36)$ and Rio Tavares $(\mathrm{n}=31)$. The other watersheds showed less than fifteen (15) publications over the selected three decades (Table 1).

Hydrology was the only subject not studied in all decades, with no registered studies in the 1990s. Land use and land cover, water quality, and socioenvironmental comprised about $21.8 \%, 20.9 \%$, and $19.9 \%$ of the total studies, respectively. Furthermore, there was an increase in researches in these knowledge areas in the last two decades, mainly in the 2000s. The third decade also showed an increase in zoology and hydrology studies (Figure 5).

Studies on land use and socio-environmental are present in all watersheds, but the more urbanized and more studied ones also presented a greater diversity of subjects explored (Figure 6).

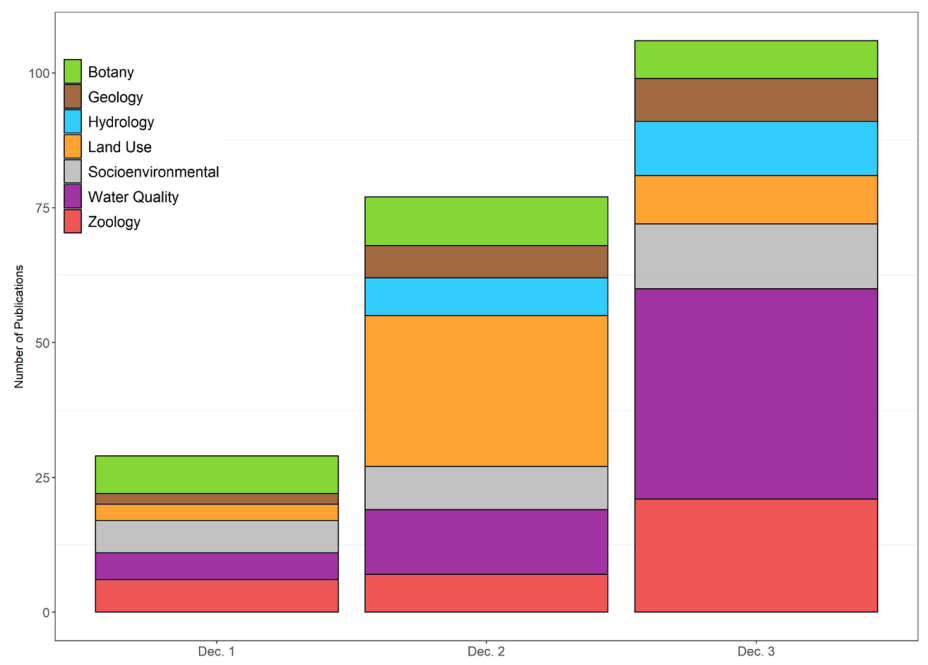

Figure 5. Number $(\mathrm{N})$ of publications on the subjects studied on the seven sub-areas of aquatic ecology in Santa Catarina Island in the last three decades (Green = botany; Brown = geology; Blue = hydrology; Orange = land use and land cover; Grey = socio-environmental; Purple = water quality; and Red = zoology).

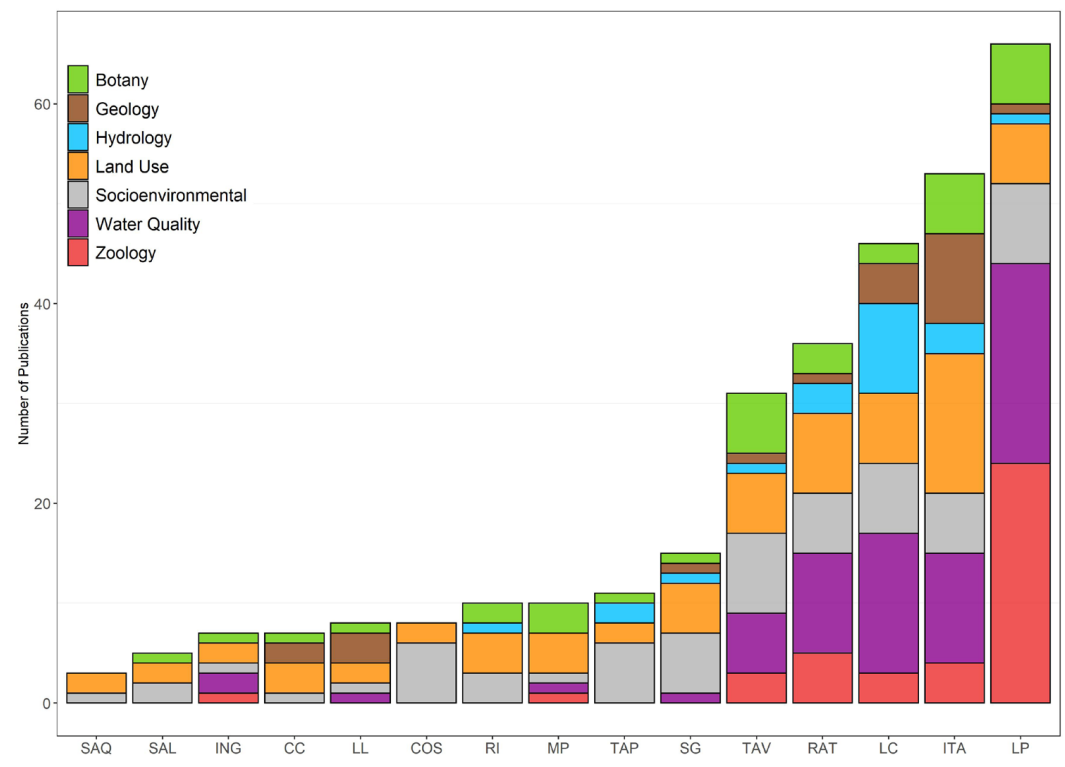

Figure 6. Number $(\mathrm{N})$ of publications on the subjects studied on the seven sub-areas of aquatic ecology in the last three decades by watersheds of Santa Catarina Island (Green = botany; Brown = geology; Blue = hydrology; Orange = land use and land cover; Grey = socio-environmental; Purple = water quality; and Red = zoology), (SAQ = Saquinho; $\mathrm{SAL}=$ Santo Antônio de Lisboa; $\mathrm{ING}=$ Ingleses; $\mathrm{CC}=$ Cacupé; $\mathrm{LL}=$ Lagoinha do Leste; $\mathrm{COS}=$ Costeira; $\mathrm{RI}=$ Ribeira da Ilha; MP = Morro das Pedras; TAP = Tapera; SG = Saco Grande; TAV = Rio Tavares; RAT = Ratones; LC = Lagoa da Conceiçăo; ITA = Itacorubi; and LP = Lagoa do Peri). 
Concerning the total urbanized area of Santa Catarina Island and total number of publications, Spearman's correlation indicated that there was a significant positive association between urbanization and the number of publications in the study area, $\left(r_{s}(29)=0.56\right.$, p-value $\left.=0.0008\right)$. However, the correlation was not significant when analyzed the urbanized areas for each watershed $\left(r_{s}(13)=-0.14, p\right.$-value $\left.=0.06\right)$, that is, more urbanized watersheds were not necessarily the ones showing the largest number of publications. On the other hand, the watershed drainage areas were positively correlated with the number of publications $\left(\mathrm{r}_{\mathrm{s}}(13)=0.63\right.$, $\mathrm{p}$-value $\left.=0.01\right)$.

\section{Discussion}

Urbanization evolution in Santa Catarina Island, mainly after the 2000s, showed a positive correlation with the number of publications on aquatic ecology, when it was analyzed the total area urbanized with the total number of publications. However, most urbanized watersheds were not necessarily the ones with the largest number of publications, while larger watersheds showed higher amount of publications.

Urban expansion in Santa Catarina Island began in the late 1960s (Campos, 2010) with the implementation of highways and the Federal University of Santa Catarina (IBAM, 2015). In addition, the $98 \mathrm{~km}$ of coast and beaches are an important tourist spot, boosting the development of new roads and resulting in subsequent urbanization (Silva et al., 1996) and a population increase of $23 \%$ in the last decade (Guerra et al., 2016). Our results showed this fast urbanization taking place between the 1990s and the 2000s, with almost twice as much of built area, mainly on the coastal area, where the occupation is concentrated (Figure 3).

We observed, in the same decades, a strong increase in the number of publications on aquatic ecology related to Santa Catarina Island, associated with the increase of urbanization. Indeed, land cover change has adversely affected aquatic ecosystems (Walsh et al., 2005; Grimm et al., 2008) and concerned scientific community, becoming an important research field, mainly after the 21 st century (Liao \& Huang, 2013).

Our results suggest that urbanization may be one of the drivers for the increasing publications on aquatic ecology. Currently, urban streams are prevalent throughout the world, and the altered ecosystem structure, with a subsequent reduction in ecosystem services, has led to an exponential increase in the number of research projects regarding urban ecosystems (Smucker \& Detenbeck, 2014).

Aquatic ecosystems have gained more attention from researchers around the world and became one of the most dynamic fields within ecology (Kong et al., 2002; Liao \& Huang, 2013). Thus, the progressive increase in the number of publications during the three decades evaluated may have led to a greater diversity of document types over time. The increase in the number of articles at the expense of the smaller number of thesis and dissertations accompanies an international trend of consolidating regional knowledge (Almeida \& Guimarães, 2013). Also, to speed up the writing and evaluation of the thesis, institutions and graduate programs in several countries, including Brazil, have chosen to replace the writing of the thesis chapters with articles.

The sub-areas found in this study were also explored in several studies of urban ecology (Karaer \& Küçükballi, 2006; Cooper et al., 2013) because they are directly affected by increased urbanization, which reinforces our findings. Indeed, studies have shown that the main causes of contamination in the Brazilian coastal zone are related to population density (Braga et al., 2006; Pagliosa et al., 2005). Others studies have shown that, despite the variety of watershed characteristics and urban development, efforts in the last two decades have been focused primarily on describing and analyzing commonalities among urban streams (Paul \& Meyer, 2001; Walsh et al., 2005; Wenger et al., 2009).

Although there is a positive relationship between total urban growth and the number of aquatic ecology studies in Santa Catarina Island, the fifteen studied watersheds have not shown a proportional increase of publications in agreement with the urban gradient (Figure 1). In other words, the most urbanized watersheds were not the same watersheds that presented the largest number of publications, evidenced by the lack of a significant correlation ( $p>0,05)$.

Nevertheless, a positive correlation between the number of publications and drainage areas (watersheds size), shows that the largest watersheds are also the most studied. The watersheds with the largest number of publications were Lagoa do Peri, Itacorubi, Ratones, Lagoa da Conceição and Rio Tavares.

The high level of economic importance of these watersheds associated with the presence of large research groups from the universities of Santa Catarina in these locations (UFSC and UDESC) 
probably has contributed to the increase in the number of studies. It is known that water quality and good ecological status within watersheds are important for the economic activities developed, as supplying drinking water (Lagoa do Peri watershed), recreation (Lagoa do Peri, Lagoa da Conceição, Itacorubi watershed) and for the maintenance of the mangrove ecosystem (Itacorubi, Ratones, and Rio Tavares) (Silva, 2019; Barbosa \& José, 1998; Torres et al., 2002).

On the other hand, watersheds which have shown less than ten (10) publications over the three decades exhibited the highest gradient of urbanization (Figure 1), except Lagoinha do Leste, Saquinho and Ribeirão da Ilha, which showed their drainage areas free of urbanization or a low-level of urban areas. It is possible that the low gradient of urbanization in these watersheds may be due to their smaller drainage areas (Table 1), constituted in a mountain chain of a high slope, corroborating with Pegas-Filho \& Tirloni (2009). Nevertheless, even in relatively pristine watersheds, alterations on streams caused by urban activities may result in decreased flow velocity and water depth, reducing habitat availability (Brasher, 2003).

Additionally, the lower number of publications associated with the higher values of the urbanized area in Costeira, Santo Antônio and Ingleses watersheds (between 22 and 29\%) and Cacupé and Morro das Pedras watersheds (more than 30\%) suggest that these streams may have their water quality and integrity compromised.

So, it is necessary to consider two reasons for the lower number of publications; first, low investment in research in the emergent and developing countries (Andrade et al., 2010), leaving gaps in the current understanding of the ecological systems. Second, most of the researchers have their fields of study focusing on one aspect or another, such as research groups that orientate their studies to a specific location (Liao \& Huang, 2013). Thus, the low number of studies could be contributing to the lack of knowledge of the water quality and availability, which is a key element for the conservation of water resources and subsequent management of these environments.

In recent years, some studies have focused on urban streams, but many questions about the mechanisms driving important changes remain unanswered (Wenger et al., 2009). Santa Catarina Island, with watersheds ranging from the relatively pristine to the highly degraded, may offer an opportunity to examine the impacts of human disturbance on water quality and native stream communities. Those coastal areas - that are sensitive to the modifications due to urbanization - are understudied and this may lead to the degradation of these resources, damaging the local economy. Understanding the relationships between habitat alteration and aquatic systems structure is critical for developing management strategies.

\section{Acknowledgements}

We thank the Institute of Urban Planning of Florianópolis (IPUF) for providing built-up data. This study was financed in part by the Coordenação de Aperfeiçoamento de Pessoal de Nível Superior - Brasil (CAPES) Finance Code 001". This collaborative work is the result of discussions held within the scope of the Inland Water Ecosystems course (ECZ5208) offered for the Biological Sciences Program at UFSC.

\section{References}

ALMEIDA, E.C. and GUIMARÃES, J.A. Brazil's growing production of scientific articles: how are we doing with review articles and other qualitative indicators? Scientometrics, 2013, 97(2), 287-315. http://dx.doi.org/10.1007/s11192-013-0967-y.

ANDRADE, H.P., RODRIGUES, F.M. and NABOUT, J.C. Análise cienciométrica global em bioindicadores: um panorama das tendências estabelecidas entre os anos 1998 a 2007. Vita et Sanitas, 2010, 4(1), 34-41.

BARBOSA, T.C.P. and JOSÉ, A.C. Lagoa da Conceição: um ecossistema lagunar: usos e legislação ambiental. Revista de Ciências Humanas, 1998, 16(23), 144-156.

BRAGA, B., PORTO, M. and TUCCI, C.E.M. Monitoramento de quantidade e qualidade das águas. In: A.C. REBOUÇAS, B. BRAGA and J.G. TUNDISI, eds. Águas doces no Brasil: capital ecológico, uso e conservação. São Paulo: Escrituras, 2006.

BRASHER, A.M.D. Impacts of human disturbances on biotic communities in Hawaiian streams. Bioscience, 2003, 53(11), 1052-1600. http://dx.doi. org/10.1641/0006-3568(2003)053[1052:IOHDO $\mathrm{B}] 2.0 . \mathrm{CO} ; 2$.

CAMPOS, E.T. A expansão urbana na Regiāo Metropolitana de Florianópolis e a dinâmica da construção civil. Florianópolis: Insular, 2010.

COOPER, S.D., LAKE, P.S., SABATER, S., MELACK, J.M. and SABO, J.L. The effects of land use changes on streams and rivers in mediterranean climates. Hydrobiologia, 2013, 719(1), 383-425. http://dx.doi. org/10.1007/s10750-012-1333-4.

DINNO, A. Conover-Iman test of multiple comparisons using rank sums [online]. Vienna: R Foundation 
for. Statistical Computing, 2017. [viewed 25 Jan. 2019]. Available from: https://cran.r-project.org/ web/packages/conover.test/conover.test.pdf

GRIMM, N.B., FOSTER, D., GROFFMAN, P.M., GROVE, J.M., HOPKINSON, C.S., NADELHOFFER, K.J., PATAKI, D.E. and PETERS, D.P.C. The changing landscape: ecosystem responses to urbanization and pollution across climatic and societal gradients. Frontiers in Ecology and the Environment, 2008, 6(5), 264-272. http:// dx.doi.org/10.1890/070147.

GRIMM, N.B., GROVE, J.M., PICKETT, S.T.A. and REDMAN, C.L. Integrated approaches to long-term studies of urban ecological systems. Bioscience, 2000, 50(7), 571-584. http://dx.doi.org/10.1641/00063568(2000)050[0571:IATLTO]2.0.CO;2.

GUERRA, J.B.S.O.A., RIBEIRO, J.M.P., FERNANDEZ, F., BAILEY, C., BARBOSA, S.B. and NEIVA, S.S. The adoption of strategies for sustainable cities: A comparative study between Newcastle and Florianópolis focused on urban mobility. Journal of Cleaner Production, 2016, 113(1), 681-694. http:// dx.doi.org/10.1016/j.jclepro.2015.07.135.

HATT, B.E., FLETCHER, T.D., WALSH, C.J. and TAYLOR, S.L. The influence of urban density and drainage infrastructure on the concentrations and loads of pollutants in small streams. Environmental Management, 2004, 34(1), 112-124. http://dx.doi. org/10.1007/s00267-004-0221-8. PMid:15383877.

INSTITUTO BRASILEIRO DE ADMINISTRAÇÃO MUNICIPAL - IBAM. Plano de ação Florianópolis Sustentável [online]. Florianópolis: IPUF, 2015 [viewed 25 Jan. 2019]. Available from: http:// www.ibam.org.br/media/arquivos/estudos/ planodeacaoflorianopolissustentavelbidcaixa.pdf

INSTITUTO DE PLANEJAMENTO URBANO DE FLORIANÓPOLIS - IPUF. Atlas do município de Florianópolis [online]. Florianópolis: IPUF, 2004. 166 p. [viewed 25 Jan. 2019]. Available from: https:// pt.scribd.com/document/296657666/Atlas-DoMunicipio-de-Florianopolis-IPUF

KARAER, F. and KÜÇÜKBALLI, A. Monitoring ofwater quality and assessment of organic pollution load in the Nilüfer stream, Turkey. Environmental Monitoring and Assessment, 2006, 114(1-3), 391417. http://dx.doi.org/10.1007/s10661-006-5029-y. PMid:16502277.

KAUSHAL, S.S., PACE, M.L., GROFFMAN, P.M., BAND, L.E., BELT, K.T., MEYER, P.M. and WELTY, C. Land use and climate variability amplify contaminant pulses. Eos, 2010, 91(25), 221-222. http://dx.doi.org/10.1029/2010EO250001.

KONG, H.M., ZHAO, J.Z., JI, L.Z., LU, Z., DENG, H.B., MA, K.M. and ZHANG, P. Assessment method of ecosystem health. Ying Yong Sheng Tai Xue Bao, 2002, 13(4), 486-490. PMid:12222060.
LIAO, J. and HUANG, Y. Global trend in aquatic ecosystem research from 1992 to 2011. Scientometrics, 2013, 98(2), 1203-1209. http://dx.doi.org/10.1007/ s11192-013-1071-z.

NASCIMENTO, R. Atlas ambiental de Florianópolis. Florianópolis: Instituto Larus, 2002.

PAGLIOSA, P.R., FONSECA, A., BOSQUILHA, G.E., BRAGA, E.S. and BARBOSA, F.A.R. Phosphorus dynamics in water and sediments in urbanized and non-urbanized rivers in Southern Brazil. Marine Pollution Bulletin, 2005, 50(9), 965-974. http:// dx.doi.org/10.1016/j.marpolbul.2005.04.005. PMid:15878601.

PARR, T.B., SMUCKER, N.J., BENTSEN, C.N. and NEALE, M.W. Potential roles of past, present, and future urbanization characteristics in producing varied stream responses. Freshwater Science, 2016, 35(1), 436-443. http://dx.doi.org/10.1086/685030.

PAUL, M.J. and MEYER, J.L. Streams in the urban landscape. Annual Review of Ecology and Systematics, 2001, 32(1), 333-365. http://dx.doi.org/10.1146/ annurev.ecolsys.32.081501.114040.

PEGAS-FILHO, A. N. and TIRLONI, D. V. Diagnóstico das bacias hidrográficas de Florianópolis. Florianópolis: Brotar e Crescer, ACIF, 2009.

PRISMA [online], 2020 [viewed 20 June 2020] Available from: http://prisma-statement.org/ PRISMAStatement/CitingAndUsingPRISMA

QGIS. Quantum Gis: a free and open Source Geographic Information System [online] 2019 [viewed 20 June 2020]. Available from: https://qgis.org/en/site/

R DEVELOPMENT CORE TEAM $R$ : A language and environment for statistical computing. Vienna: R Foundation for Statistical Computing, 2015. Available from: http://www.R-project.org/.

SANTIAGO, A.G., MICHELETI, T., MATÉ, C., WEISS, R., CORREIA, A.C.D.I. and SABOYA, R.T. Espaços livres e forma urbana: interpretando características e conflitos em Florianópolis (SC). Paisagem e Ambiente: Ensaios, 2014, 33, 49-66.

SAVICKY, P. Spearman's rank correlation test. 2015 [viewed 25 Jan. 2019]. Available from: https://cran.rproject.org/web/packages/pspearman/pspearman. pdf.

SILVA, A.R. Avaliação do processo de eutrofização das águas superficiais, do cenário nacional ao local: estudo de caso nas Bacias Hidrográficas Costeiras dos Rios Ratones, Itacorubi e Tavares (Ilha de Santa Catarina, Brasil) [Tese de Doutorado em Geografia]. Florianópolis: Programa de Pós-graduação em Geografia, Centro de Filosofia e Ciências Humanas, Universidade Federal de Santa Catarina, 2019, 309 p.

SILVA, M.R., LAMOTTE, M., DONARD, O.F.X., SORIANO-SIERRA, E.J. and ROBERT, M. Metal contamination in surface sediments of mangroves, lagoons and Southern Bay in Florianopolis Island. 
Environmental Technology, 1996, 17(10), 1035-1046. http://dx.doi.org/10.1080/09593331708616473.

SISTEMAS DE INFORMAÇÓES GEOGRÁFICAS DE SANTA CATARINA - SIGSC. 2017 [viewed 15 Dez. 2018]. Available from: http://sigsc.sds.sc.gov. br/download/index.jsp.

SMUCKER, N.J. and DETENBECK, N.E. Metaanalysis of lost ecosystem attributes in urban streams and the effectiveness of out-of-channel management practices. Restoration Ecology, 2014, 22(6), 741-748. http://dx.doi.org/10.1111/rec.12134.

TORRES, M.A., TESTA, C.P., GÁSPARI, C., MASUTTI, M.B., PANITZ, C.M.N., CURIPEDROSA, R., ALMEIDA, E.A., DI MASCIO, P. and WHILHELMFILHO, D. Oxidative stress in the mussel Mytella guyanensis from polluted mangroves on Santa Catarina Island, Brazil. Marine Pollution Bulletin, 2002, 44(9), 923-932. http://dx.doi.org/10.1016/ S0025-326X(02)00142-X. PMid:12405217.

VAN RAAN, A.F.J. For your citations only? Hot topics in bibliometric analysis. Measurement: Interdisciplinary Research and Perspectives, 2005, 3(1), 50-62. http:// dx.doi.org/10.1207/s15366359mea0301_7.

WALSH, C.J., ROY, A., FEMINELLA, J.W., COTTINGHAM, P.D., GROFFMAN, P.M. and MORGAN 2ND, R.P. . The urban stream syndrome: current knowledge and the search for a cure. Journal of the North American Benthological Society, 2005, 24(3), 706-723. http://dx.doi.org/10.1899/04-028.1.

WEMPLE, B.C., BROWNING, T., ZIEGLER, A.D., CELI, J., CHUN, K.P.S., JARAMILLO, F, LEITE, N.K., RAMCHUNER, S.J., NEGISHI, J.N., PALOMEQUE, X. and SAWYER, D. Ecohydrological disturbances associated with roads: current knowledge, research needs and management concerns with reference to the tropics. Ecohydrology, 2017, 11(3), 1-23.

WENGER, S.J., ROY, A.H., JACKSON, C.R., BERNHARDT, E.S., CARTER, T.L., FILOSO, S., GIBSON, C.A., HESSION, W.C., KAUSHAL, S.S., MARTI, E., MEYER, J.L., PALMER, M.A., PAUL, M.J., PURCELL, A.H., RAMIREZ, A., ROSEMOND, A.D., SCHOFIELD, K.A., SUDDUTH, E.B. and WALSH, C.J. Twenty-six key research questions in urban stream ecology: an assessment of the state of the science. Journal of the North American Benthological Society, 2009, 28(4), 1080-1098. http://dx.doi.org/10.1899/08-186.1.

Received: 20 August 2019

Accepted: 01 July 2020

Associate Editors: André Megali Amado, Joyce Andreia dos Santos, Rafael Marques Almeida, Simone Jaqueline Cardoso. 